Article

\title{
Postmenopausal Women Have Higher HDL and Decreased Incidence of Low HDL than Premenopausal Women with Metabolic Syndrome
}

\author{
Maria Luz Fernandez * and Ana Gabriela Murillo \\ Department of Nutritional Sciences, University of Connecticut, Storrs, CT 06269, USA; \\ ana.murillo_solis@uconn.edu \\ * Correspondence: maria-luz.fernandez@uconn.edu; Tel.: +1-860-486-5547 \\ Academic Editor: Sampath Parthasarathy \\ Received: 10 February 2016; Accepted: 10 March 2016; Published: 16 March 2016
}

\begin{abstract}
It is well known that plasma lipids, waist circumference (WC) and blood pressure (BP) increase following menopause. In addition, there is a perceived notion that plasma high-density lipoprotein-cholesterol (HDL-C) concentrations also decrease in postmenopausal women. In this cross-sectional study, we evaluated plasma lipids, fasting glucose, anthropometrics and BP in 88 post and 100 pre-menopausal women diagnosed with metabolic syndrome. No differences were observed in plasma low-density lipoprotein-cholesterol cholesterol, triglycerides, fasting glucose or systolic and diastolic BP between groups. However, plasma HDL-C was higher $(p<0.01)$ in postmenopausal women and the percentage of women who had low HDL $(<50 \mathrm{mg} / \mathrm{dL})$ was higher $(p<0.01)$ among premenopausal women. In addition, negative correlations were found between WC and HDL-C $(r=-0.148, p<0.05)$ and BMI and HDL-C $(r=-0.258, p<0.01)$ for all subjects indicating that increases in weight and abdominal fat have a deleterious effect on plasma HDL-C. Interestingly, there was a positive correlation between age and plasma HDL-C $(r=0.237 p<0.01)$. The results from this study suggest that although HDL is decreased by visceral fat and overall weight, low HDL is not a main characteristic of metabolic syndrome in postmenopausal women. Further, HDL appears to increase, not decrease, with age.
\end{abstract}

Keywords: postmenopausal women; premenopausal women; HDL cholesterol; age; waist circumference; body mass index

\section{Introduction}

Menopause is defined as the cessation of menses due to estrogen deficiency for at least one year [1,2], which in North America happens at a median age of 51 [3]. Post-menopausal women may experience a variety of symptoms, including hot flashes, sweating, insomnia, and vaginal dryness and general discomfort [1,4]. In addition, most women undergo physiological changes in the first years following their final menstrual period [3].

One of the physiological changes that occurs during menopause is an increase in body weight [3,5-7]. Although the normal aging process is associated with a decreased lean body mass and a slower metabolic rate regardless of sex or hormonal status [6], postmenopausal women tend to experience an accelerated weight gain during the first years of endogenous estrogen decline $[5,8]$. In addition to overall weight gain, menopause is also linked to changes in body composition and fat distribution [9]. With increasing postmenopausal age, lean body mass decreases while fat mass increases [5,6], predominantly in the abdominal area $[3,6,10,11]$. This augmented visceral adipose tissue (VAT) is positively associated with cardiovascular risk factors and metabolic diseases $[12,13]$ and it is considered one of the components of the metabolic syndrome (MetS) [14]. 
MetS is a cluster of clinical criteria used to identify patients at increased risk for cardiovascular disease (CVD), type II diabetes mellitus (T2DM) and all-cause mortality. These risk factors are hypertension ( $\geqslant 130 / 85 \mathrm{~mm} \mathrm{Hg}$ ), decreased high-density lipoprotein- cholesterol (HDL-C) $(<40 \mathrm{mg} / \mathrm{dL}$ for men and $<50 \mathrm{mg} / \mathrm{dL}$ for women) hypertriglyceridemia (triglycerides $\geq 150 \mathrm{mg} / \mathrm{dL}$ ), high fasting blood glucose ( $\geq 100 \mathrm{mg} / \mathrm{dL}$ ) and abdominal obesity (waist circumference of $\geqslant 102 \mathrm{~cm}$ for males and $\geqslant 88 \mathrm{~cm}$ for females) $[15,16]$. Increased weight and obesity lead to higher prevalence of MetS in postmenopausal women and this may explain, in part, why there is a twofold increase in risk for CVD after menopause $[8,14,17]$.

Another physiological change that occurs during menopause is a shift towards a more atherogenic lipid profile $[8,14]$. After the cessation of menses, researchers have found an increase in plasma triglycerides (TG), total cholesterol (TC) and low-density lipoprotein-cholesterol (LDL-C), especially the small and dense particles which are more pro-atherogenic $[8,14,18,19]$. These changes seem to be independent of age and more related to the increased abdominal fat mass [8].

An important component of the lipid profile is HDL-C concentration and size of HDL particles [20]. Clinical and epidemiological data have provided evidence of an inverse relationship between low concentration of HDL-C and an increased risk for CVD [21]. HDL particles not only mediate reverse cholesterol transport (RCT) but also exhibit anti-oxidant, anti-inflammatory, anti-thrombotic and vasodilatory activities [22-24]. The changes in the concentration of HDL-C and HDL particles composition after menopause have been subject of controversy. While some authors state that there is a decrease of HDL-C in post-menopausal women [8,14,19], others have reported no changes [25] or even an increase in HDL-C after menopause [26,27]. In the present study, the MetS parameters of premenopausal $(n=100)$ and post-menopausal women $(n=88)$ who were recruited from 2009 to 2015 as participants of different interventions are compared at baseline to analyze the differences observed between these two groups. We hypothesized that HDL-C would not be lower in postmenopausal women and that abdominal fat would be a better predictor of plasma HDL-C concentrations.

\section{Materials and Methods}

\subsection{Subjects}

We analyzed the baseline characteristics of pre $(n=100)$ and post-menopausal women $(n=88)$ who were recruited from 2009 to 2015 as participants of interventions targeted at metabolic syndrome [28-31]. In the current study, we evaluated plasma lipids, anthropometrics, plasma glucose and blood pressure at baseline (prior to the intervention) to compare these parameters between groups. All human studies were approved by the University of Connecticut Institutional Research Board and all subjects signed an informed consent to participate.

\subsection{Anthropometrics and Blood Pressure}

Body weight was recorded to the nearest $100 \mathrm{~g}$ on a calibrated digital scale, with subjects wearing only light clothing. Height was measured to the closest $\mathrm{cm}$. Both height and weight were used to calculate BMI as $\mathrm{kg} / \mathrm{m}^{2}$. Waist circumference (WC) was measured by using a non-flexible tape, which was placed directly on the skin with the participant having feet together and arms hanging freely. All WC measurements were done to the nearest $0.1 \mathrm{~cm}$ immediately above the iliac crest and repeated 3 times for a precise average measurement. Blood pressure was measured on the left arm using an Omron HEM-711 DLX automated blood pressure monitor (Omron healthcare, Inc., Bannockburn, IL, USA) with subjects seated, following a 5-10 min rest.

\subsection{Blood Sample Collection}

After a 12-h overnight fast, blood samples were drawn from each subject. A total of $60 \mathrm{~mL}$ blood was collected from the antecubital vein into EDTA- containing tubes to prevent coagulation. Plasma was separated by centrifugation at $2000 \times g$ for $20 \mathrm{~min}$ at $4{ }^{\circ} \mathrm{C}$. Subsequently, phenylmethylsulfonyl 
fluoride $(0.1 \mathrm{~mL} / 100 \mathrm{~mL})$, sodium azide $(0.1 \mathrm{~mL} / 100 \mathrm{~mL})$ and aprotinin $(0.5 \mathrm{~mL} / 100 \mathrm{~mL})$ were added for preservation after plasma was separated from red blood cells. Plasma samples were then aliquoted and frozen at $-80^{\circ} \mathrm{C}$ until further analysis.

\subsection{Plasma Lipids and Glucose}

Plasma total cholesterol, HDL-C, TG and glucose were all measured using an automated clinical chemistry analyzer (Cobas C 111, Roche Diagnostics, Indianapolis, IN, USA) or via enzymatic methods. Plasma LDL-cholesterol (LDL-C) was estimated by the Friedewald equation [32]. None of the participants had plasma TG $>400 \mathrm{mg} / \mathrm{dL}$ thus the calculation of LDL-C by the Friedwald equation was appropriate.

\subsection{Statistical Analysis}

All values are presented as mean \pm SD. Un-paired $t$-tests were used to compare pre and postmenopausal women in the measured parameters. When women were classified in low and HDL cholesterol groups, a two-way ANOVA was used to evaluate menopause effect, low HDL effect and interaction. Pearson correlations were done to correlate between anthropometrics and HDL cholesterol and age and plasma HDL-C. A $p$ value $<0.05$ was considered to be significant.

\section{Results}

\section{Age, Plasma Lipids, Plasma Glucose, Anthropometrics and Blood Pressure}

The values for age, plasma lipids, glucose and anthropometrics are indicated in Table 1. There were no significant differences in body weight, BMI, WC, blood pressure, total cholesterol, LDL cholesterol, triglycerides or glucose between pre and postmenopausal women. Age was different $(p<0.001)$ as expected due to menopausal status. Surprisingly, HDL cholesterol was higher $(p<0.001)$ in postmenopausal women by $11 \%$. Further, the number of women who had low HDL cholesterol was higher in pre vs. postmenopausal women (Table 1). The range of ages were 26-49 years for pre-menopausal and 51-74 years for postmenopausal women.

Table 1. Anthropometrics, blood pressure plasma lipids and plasma glucose of premenopausal and postmenopausal women with metabolic syndrome ${ }^{1}$.

\begin{tabular}{|c|c|c|c|}
\hline Parameter & $\begin{array}{l}\text { Premenopausal Women } \\
\qquad(n=100)\end{array}$ & $\begin{array}{l}\text { Postmenopausal Women } \\
\qquad(n=88)\end{array}$ & $p$ Value \\
\hline Age (years) & $40.7 \pm 7.9$ & $57.4 \pm 5.8$ & $p<0.001$ \\
\hline Number of MetS Parameters & $3.4 \pm 0.6$ & $3.3 \pm 0.6$ & $\mathrm{NS}^{2}$ \\
\hline Body Weight $(\mathrm{kg})$ & $90.0 \pm 13.5$ & $88.4 \pm 17.5$ & NS \\
\hline BMI $\left(\mathrm{kg} / \mathrm{m}^{2}\right)$ & $34.0 \pm 5.3$ & $33.0 \pm 6.1$ & NS \\
\hline $\mathrm{WC}^{3}(\mathrm{~cm})$ & $105.6 \pm 10.7$ & $107.6 \pm 12.0$ & NS \\
\hline Systolic BP 4 (mm Hg) & $128.2 \pm 15.6$ & $125.6 \pm 15.2$ & NS \\
\hline Diastolic BP (mm Hg) & $81.3 \pm 9.7$ & $81.7 \pm 8.5$ & NS \\
\hline $\mathrm{TC}^{5}(\mathrm{mg} / \mathrm{dL})$ & $216.6 \pm 34.4$ & $216.1 \pm 37.7$ & NS \\
\hline LDL-C (mg/dL) & $136.9 \pm 33.3$ & $134.6 \pm 35.2$ & NS \\
\hline HDL-C (mg/dL) & $46.7 \pm 10.7$ & $51.7 \pm 14.9$ & $p<0.01$ \\
\hline $\mathrm{TG}^{6}(\mathrm{mg} / \mathrm{dL})$ & $163.9 \pm 62.5$ & $167.5 \pm 67.0$ & NS \\
\hline Glucose (mg/dL) & $96.5 \pm 12.3$ & $99.4 \pm 13.7$ & NS \\
\hline Low $\mathrm{HDL}^{7}(\%)$ & $67 \%$ & $46.5 \%$ & $p<0.01$ \\
\hline
\end{tabular}

${ }^{1}$ : Values are presented as mean \pm SD for the number of participants indicated in parentheses; $p$ values were determined by use of non-paired $t$-test; ${ }^{2}$ : Non-significant; ${ }^{3}$ : waist circumference; ${ }^{4}$ : blood pressure; ${ }^{5}$ : total cholesterol; ${ }^{6}$ : triglycerides; ${ }^{7}:$ HDL $<50 \mathrm{mg} / \mathrm{dL}$.

Although there were no significant differences in MetS parameters between pre- and postmenopausal women, the most consistent parameters contributing to this classification were WC, 
plasma TG and HDL-C for premenopausal women and WC, plasma TG and blood glucose for postmenopausal women. Interestingly the majority of the subjects only had three parameters of MetS and only two in each group (pre and post-menopausal) had 5 MetS parameters.

In agreement with the results reported in Table 1, significant correlations were found between HDL cholesterol and age for all participants as indicated in Figure 1. These findings suggest that low HDL-C is a more important parameter for MetS classification in the younger women than in those undergoing menopause.

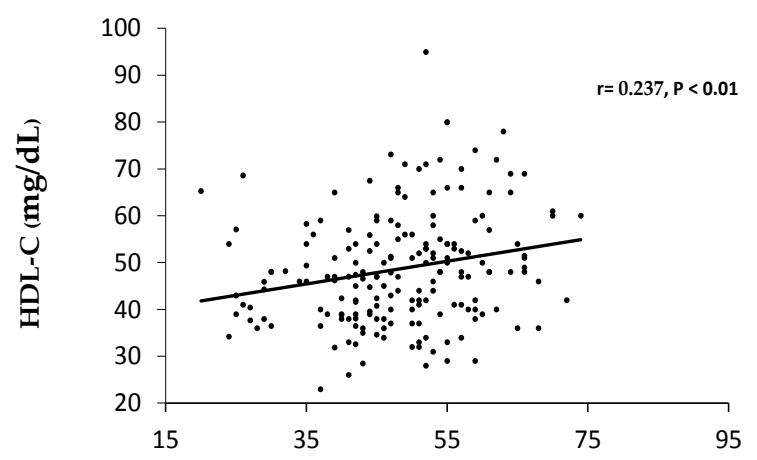

Age (years)

Figure 1. Correlation between age and HDL cholesterol in pre $(n=100)$ and postmenopausal $(n=88)$ women.

Both pre and post-menopausal women were classified according to HDL cholesterol distribution into: low HDL $(<50 \mathrm{mg} / \mathrm{dL})$ and high HDL $(\geqslant 50 \mathrm{mg} / \mathrm{dL})$. As indicated in Table 2, menopause did not affect any parameter except for age. However HDL status affected: age, LDL-C, HDL-C and TG. Women with higher HDL were older $(p<0.05)$, had lower LDL-C $(p<0.01)$ and lower plasma TG $(p<0.001)$.

Table 2. Distribution of pre and post-menopausal women into Low HDL and High HDL groups ${ }^{1}$.

\begin{tabular}{|c|c|c|c|c|c|c|}
\hline \multirow[b]{2}{*}{ Parameter } & \multicolumn{2}{|c|}{ Pre-Menopausal Women } & \multicolumn{2}{|c|}{ Post-Menopausal Women } & \multicolumn{2}{|c|}{$p$ Value } \\
\hline & $\begin{array}{l}\text { Low HDL } \\
(n=67)\end{array}$ & $\begin{array}{l}\text { High HDL } \\
(n=33)\end{array}$ & $\begin{array}{l}\text { Low HDL } \\
(n=41)\end{array}$ & $\begin{array}{l}\text { High HDL } \\
(n=47)\end{array}$ & $\begin{array}{l}\text { Meno-Pause } \\
\text { Effect }\end{array}$ & $\begin{array}{c}\text { Low HDL } \\
\text { Effect }\end{array}$ \\
\hline Age (years) & $39.8 \pm 7.3$ & $42.6 \pm 8.7$ & $57.1 \pm 5.7$ & $57.7 \pm 5.9$ & $<0.001$ & 0.05 \\
\hline Body Weight (kg) & $89.7 \pm 12.9$ & $91.0 \pm 15.1$ & $89.1 \pm 17.4$ & $87.8 \pm 17.7$ & $\mathrm{NS}^{2}$ & NS \\
\hline BMI $\left(\mathrm{kg} / \mathrm{m}^{2}\right)$ & $34.3 \pm 5.4$ & $33.6 \pm 6.2$ & $33.7 \pm 6.2$ & $32.3 \pm 6.0$ & NS & NS \\
\hline $\mathrm{WC}^{3}(\mathrm{~cm})$ & $105 \pm 10$ & $107 \pm 12$ & $109 \pm 12^{a}$ & $106 \pm 12^{b}$ & NS & 0.01 \\
\hline Systolic $\mathrm{BP}^{4}(\mathrm{~mm} \mathrm{Hg})$ & $130 \pm 15$ & $126 \pm 16$ & $126 \pm 16$ & $126 \pm 15$ & NS & NS \\
\hline Diastolic BP (mm Hg) & $81.4 \pm 10.3$ & $81.7 \pm 8.5$ & $81.4 \pm 9.7$ & $82.9 \pm 8.7$ & NS & NS \\
\hline $\mathrm{TC}^{5}(\mathrm{mg} / \mathrm{dL})$ & $216 \pm 33$ & $220 \pm 32$ & $217 \pm 37$ & $218 \pm 36$ & NS & NS \\
\hline LDL-C (mg/dL) & $142 \pm 33^{\mathrm{a}}$ & $126 \pm 3^{b}$ & $140 \pm 39^{a}$ & $130 \pm 32^{b}$ & NS & 0.01 \\
\hline HDL-C (mg/dL) & $42.7 \pm 5.6^{\mathrm{a}}$ & $58.9 \pm 7.1^{b}$ & $40.3 \pm 6.2^{\mathrm{a}}$ & $61.7 \pm 13.0^{b}$ & NS & $<0.001$ \\
\hline $\mathrm{TG}^{6}(\mathrm{mg} / \mathrm{dL})$ & $167 \pm 63^{\mathrm{a}}$ & $171 \pm 49^{\mathrm{a}}$ & $202 \pm 67^{a}$ & $138 \pm 52^{b}$ & NS & $<0.001$ \\
\hline Glucose (mg/dL) & $97 \pm 11$ & $96 \pm 14$ & $101 \pm 16$ & $99 \pm 11$ & NS & NS \\
\hline
\end{tabular}

${ }^{1}$ : Values are presented as mean \pm SD for the number of participants indicated in parentheses; $p$ values were calculated by use of two-way ANOVA. Numbers with different superscripts $(a, b)$ indicate that there is a significant interaction effect; ${ }^{2}$ : Non-significant; ${ }^{3}$ : waist circumference; ${ }^{4}$ : blood pressure; ${ }^{5}$ : total cholesterol; ${ }^{6}$ : triglycerides.

Significant negative correlations were found between HDL-C and BMI (Figure 2) and HDL-C and WC (Figure 3) for all subjects suggesting that accumulation of body fat has a detrimental effect on plasma HDL-C. 


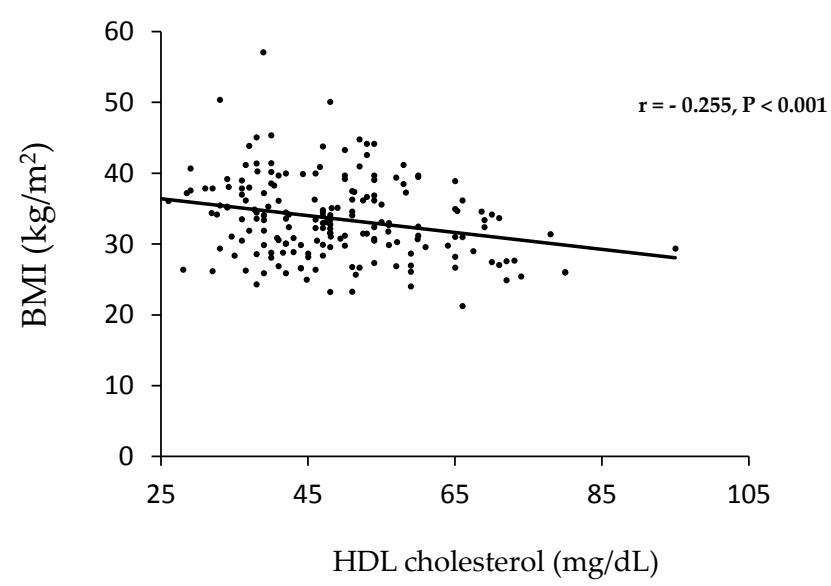

Figure 2. Correlation between HDL cholesterol and body mass index for pre $(n=100)$ and postmenopausal $(n=88)$ women.

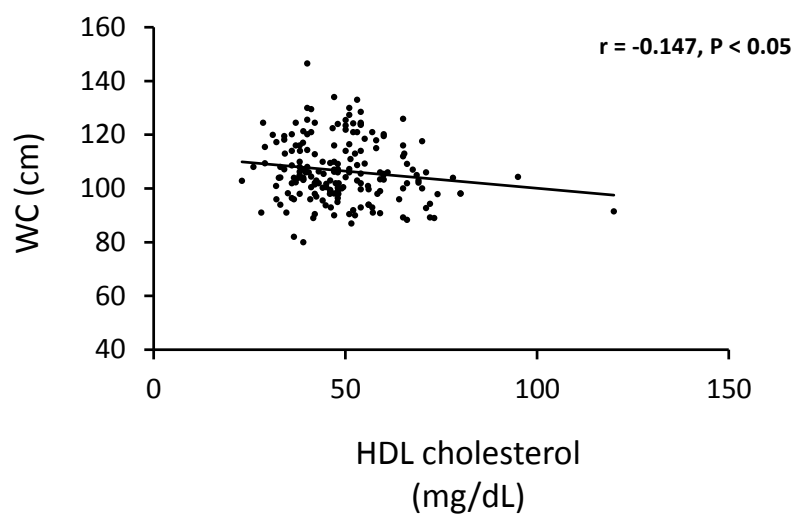

Figure 3. Correlation between HDL cholesterol and waist circumference in 100 pre and 88 postmenopausal women.

\section{Discussion}

Menopause is characterized by increases in a number of biomarkers that are associated with higher risk for heart disease and T2DM including visceral adiposity $[10,14,33]$, diastolic and systolic BP [34,35], plasma glucose [8,36], atherogenic lipoproteins [8] and inflammatory markers [8,37]. Some of these biomarkers are part of the criteria for MetS, which explains why the overall prevalence for this condition in the United States goes from $22.6 \%$ to over $50 \%$ after menopause [38,39]. It is a general understanding that menopause also causes a decrease in the concentration of HDL-C $[8,14,36,40]$, which is another component of MetS [41]; however, in this study we demonstrated that HDL-C is not lower in postmenopausal women when compared with premenopausal women with MetS. In fact, HDL-C concentrations in this study were higher in post- compared to pre-menopausal women. This interesting finding has also been observed by other investigators [25-27]. It is possible that the observed increase in HDL-C in postmenopausal women could be due to a protective mechanism to counterbalance the deleterious effects of biomarkers associated with menopause. However, further studies are needed to confirm this theory.

An important observation in these analyses was that HDL-C was negatively correlated to WC, a biomarker of visceral obesity, as well as to BMI. These correlations have been reported by other investigators in heterogeneous populations [42-45]. This relationship between WC and HDL-C concentrations can be explained by the changes in fat depots which have an important impact in lipoprotein metabolism [46]. An augmented VAT is positively associated with an increased release of 
free fatty acids (FFA) into the bloodstream, which among other effects, leads to an increased activity of the hepatic lipase [8]. This amplified activity has been associated with low serum concentrations of HDL-C [46,47] because hepatic lipase could convert large, triglyceride rich HDL particles into small HDL particles, which are cleared more rapidly from the circulation [48].

Abdominal obesity is also reported to be associated with other metabolic complications including insulin resistance, glucose intolerance, small and dense LDL, inflammation, altered cytokine profile and endothelial dysfunction [13] which explain why WC is such a strong predictor of cardiovascular disease, hyperlipidemia and T2DM [49,50]. This relationship between HDL-C and WC also helps explain why some authors found HDL-C concentrations to be lower in in post-menopausal women.

One of the physiological changes associated with menopause besides weight gain is a change in body fat distribution [9], which some authors describe as a transition from a gynecoid to an android pattern of fat depots [3]. This means that after menopause VAT increases significantly, independently of age, which suggests that female fat distribution is influenced by sex hormone concentrations $[10,33,51]$. It is then possible that low HDL-C concentrations observed by some investigators after menopause are not directly caused by menopause but are a consequence of VAT augmentation commonly observed in post-menopausal women. It is also possible that women in which VAT remains unaltered after menopause would have unchanged or even increased HDL-C concentrations, as it is shown in the present study, supporting the hypothesis that menopause does not decrease HDL-C concentration perse.

The high concentrations of HDL-C as well as the number of HDL particles have been correlated with numerous healthy benefits not just the well-established role of HDL in RCT [23,52,53]. For example, HDL has been shown to carry important antioxidants in plasma including the carotenoids lutein and zeaxanthin [54], paraoxonase 1, platelet activating factor acetyl-hydrolase, glutathione peroxidase [22]. These antioxidant activities help reduce oxidative stress and thus, LDL oxidation, which is pivotal to the development of atherosclerosis and subsequent cardiovascular diseases [52,55]. In addition, HDL also carries sphingosine-1-phosphate, a molecule that when associated with HDL, could be responsible for the beneficial effects of these lipoprotein on vasorelaxation, cell survival, cell adhesiveness and angiogenesis [56]. Overall, HDL has shown anti-oxidant, anti-inflammatory, anti-thrombotic and anti-apoptotic properties which is why dietary or pharmacological strategies to increase this lipoprotein and its functionality are so important in the prevention of cardiovascular diseases and other metabolic morbidities [22-24].

Furthermore, all the women analyzed in this study, whether pre- or post-menopausal with normal values for HDL-C ( $\geqslant 50 \mathrm{mg} / \mathrm{dL})$, also presented lower concentrations of both LDL-C and TG constituting overall a more favorable lipoprotein profile [57]. Thus, VAT and body weight appear to have a greater influence on the dyslipidemias associated with MetS, independent of age and hormonal status. Although these conclusions may have been reached in other analysis, what makes this study unique is the comparisons between pre- and post-menopausal women and the confirmation that HDL-C is not a major risk factor for the older population.

\section{Limitations}

One of the limitations of this study is that the analysis was conducted exclusively with women with MetS, which only describes the phenomena of HDL and menopause in a context of metabolic abnormalities where low HDL is one of the criteria. In addition, the other symptoms of MetS are variable and each individual parameter can affect HDL-C differently. Further studies are needed to compare HDL-C at different ages in other populations, for example, healthy, diabetic or overweight individuals.

Another limitation is that there are techniques available to measure HDL functionality [58] however, the present manuscript does not report HDL functionality, only HDL-C concentrations. Studies have reported that absolute HDL concentrations are poor indicators of HDL functional capacity [59]. This is important because some patients with elevated HDL-C concentrations could 
remain at risk for coronary events if HDL is not functional $[60,61]$ and some authors have suggested that this could be the case for menopausal women [62].

\section{Conclusions}

From these data, we conclude that women with increased weight and visceral fat are at a higher risk for developing dyslipidemias characterized by high TG and low HDL-C. The lower HDL-C concentrations, which are normally related to increased oxidative stress and inflammation, were more prominent in premenopausal women suggesting that younger women with MetS are at increased risk for heart disease and possibly diabetes than their older counterparts. For women with MetS, WC and BMI are more accurate predictors of HDL-C concentrations, and thus, cardiovascular risk, than menopausal status.

Acknowledgments: This data analysis did not receive any support source. No financial support was given to publish this paper on line.

Author Contributions: Maria Luz Fernandez analyzed the data, prepared the figures and tables and contributed to the interpretation of data and the writing of the manuscript. Ana Gabriela Murillo contributed to data interpretation and writing of the manuscript.

Conflicts of Interest: Maria Luz Fernandez and Ana Gabriela Murillo declare no conflict of interest of the manuscript, and in the decision to publish the results.

\section{Abbreviations}

The following abbreviations are used in this manuscript:

$\begin{array}{ll}\text { BMI } & \text { body mass index } \\ \text { BP } & \text { blood pressure } \\ \text { FBG } & \text { fasting blood glucose } \\ \text { FFA } & \text { free fatty acids } \\ \text { HDL } & \text { high density lipoprotein } \\ \text { HDL-C } & \text { HDL cholesterol } \\ \text { LDL-C } & \text { LDL cholesterol } \\ \text { MetS } & \text { metabolic syndrome } \\ \text { RTC } & \text { reverse cholesterol transport } \\ \text { TG } & \text { triglycerides } \\ \text { VAT } & \text { visceral adipose tissue } \\ \text { WC } & \text { waist circumference }\end{array}$

\section{References}

1. Goodman, N.F.; Cobin, R.H.; Ginzburg, S.B.; Katz, I.A.; Woode, D.E. AACE medical guidelines for clinical practice for the diagnosis and treatment of menopause. Endocr. Pract. 2011, 17, 1-25. [CrossRef] [PubMed]

2. Weismiller, D.G. Menopause. Prim. Care Clin. Off. Pract. 2009, 36, 199-226. [CrossRef] [PubMed]

3. Al-Safi, Z.A.; Polotsky, A.J. Obesity and menopause. Best Pract. Res. Clin. Obstet. Gynaecol. 2015, 29, 548-553. [CrossRef] [PubMed]

4. Bruce, D.; Rymer, J. Symptoms of the menopause. Best Pract. Res. Clin. Obstet. Gynaecol. 2009, 23, 25-32. [CrossRef] [PubMed]

5. Dubnov, G.; Brzezinski, A.; Berry, E.M. Weight control and the management of obesity after menopause: The role of physical activity. Maturitas 2003, 44, 89-101. [CrossRef]

6. Panotopoulos, G.; Raison, J.; Ruiz, J.C.; Guy-Grand, B.; Basdevant, A. Weight gain at the time of menopause. Hum. Reprod. 1997, 12, 126-133. [CrossRef] [PubMed]

7. Davis, S.R.; Castelo-Branco, C.; Chedraui, P.; Lumsden, M.A.; Nappi, R.E.; Shah, D.; Villaseca, P. Understanding weight gain at menopause. Climacteric 2012, 15, 419-429. [CrossRef] [PubMed]

8. Polotsky, H.N.; Polotsky, A.J. Metabolic implications of menopause. Semin. Reprod. Med. 2010, 28, 426-434. [CrossRef] [PubMed] 
9. Ley, C.J.; Belinda Lees, B.; Stevenson, J.C. Sex- and menopause-associated in body-fat distribution. Am. J. Clin. Nutr. 1992, 55, 950-954. [PubMed]

10. Toth, M.J.; Tchernof, A.; Sites, C.K.; Poehlman, E.T. Menopause-related changes in body fat distribution. Ann. N. Y. Acad. Sci. 2000, 904, 502-506. [CrossRef] [PubMed]

11. Franklin, R.M.; Ploutz-Snyder, L.; Kanaley, J.A. Longitudinal changes in abdominal fat distribution with menopause. Metabolism 2009, 58, 311-315. [CrossRef] [PubMed]

12. Matsushita, Y.; Nakagawa, T.; Yamamoto, S.; Kato, T.; Ouchi, T.; Kikuchi, N.; Takahashi, Y.; Yokoyama, T.; Mizoue, T.; Noda, M. Adiponectin and visceral fat associate with cardiovascular risk factors. Obesity 2014, 22, 287-291. [CrossRef] [PubMed]

13. Després, J.P. Body fat distribution and risk of cardiovascular disease: An update. Circulation 2012, 126, 1301-1313. [CrossRef] [PubMed]

14. Carr, M.C. The emergence of the metabolic syndrome with menopause. J. Clin. Endocrinol. Metab. 2003, 88, 2404-2411. [CrossRef] [PubMed]

15. Calton, E.K.; Miller, V.S.; Soares, M.J. Factors determining the risk of the metabolic syndrome: Is there a central role for adiponectin? Eur. J. Clin. Nutr. 2013, 67, 485-491. [CrossRef] [PubMed]

16. Beltran-Sanchez, H.; Harhay, M.; Harhay, M.; McElligott, S. Prevalence and trends of metabolic sydrome in the adult US population, 1999-2010. J. Am. Coll. Cardiol. 2014, 62, 697-703. [CrossRef] [PubMed]

17. Jouyandeh, Z.; Nayebzadeh, F.; Qorbani, M.; Asadi, M. Metabolic syndrome and menopause. J. Diabetes Metab. Disord. 2013. [CrossRef] [PubMed]

18. Carmena, R. Atherogenic lipoprotein particles in atherosclerosis. Circulation 2004. [CrossRef] [PubMed]

19. Anagnostis, P.; Stevenson, J.C.; Crook, D.; Johnston, D.G.; Godsland, I.F. Effects of menopause, gender and age on lipids and high-density lipoprotein cholesterol subfractions. Maturitas 2015, 81, 62-68. [CrossRef] [PubMed]

20. Santos-Gallego, C.G.; Badimon, J.J.; Rosenson, R.S. Beginning to understand high-density lipoproteins. Endocrinol. Metab. Clin. N. Am. 2014, 43, 913-947. [CrossRef] [PubMed]

21. Santos-Gallego, C.G.; Badimón, J.J. High-density lipoprotein and cardiovascular risk reduction: Promises and realities. Rev. Esp. Cardiol. 2012, 65, 305-308. [CrossRef] [PubMed]

22. Assmann, G.; Gotto, A.M. HDL cholesterol and protective factors in atherosclerosis. Circulation 2004, 109, III8-III14. [CrossRef] [PubMed]

23. Andersen, C.J.; Fernandez, M.L. Dietary approaches to improving atheroprotective HDL functions. Food Funct. 2013, 4, 1304-1313. [CrossRef] [PubMed]

24. Ali, K.M.; Wonnerth, A.; Huber, K.; Wojta, J. Cardiovascular disease risk reduction by raising HDL cholesterol-Current therapies and future opportunities. Br. J. Pharmacol. 2012, 167, 1177-1194. [CrossRef] [PubMed]

25. Zhou, J.-L.; Lin, S.-Q.; Shen, Y.; Chen, Y.; Zhang, Y.; Chen, F.-L. Serum lipid profile changes during the menopausal transition in Chinese women: a community-based cohort study. Menopause 2010, 17, 997-1003. [CrossRef] [PubMed]

26. Kim, C.J.; Kim, T.H.; Ryu, W.S.; Ryoo, U.H. Influence of menopause on high density lipoprotein-cholesterol and lipids. J. Korean Med. Sci. 2000, 15, 380-386. [CrossRef] [PubMed]

27. Derby, C.A.; Crawford, S.L.; Pasternak, R.C.; Sowers, M.; Sternfeld, B.; Matthews, K.A. Lipid changes during the menopause transition in relation to age and weight. Am. J. Epidemiol. 2009, 169, 1352-1361. [CrossRef] [PubMed]

28. Blesso, C.N.; Andersen, C.J.; Barona, J.; Volek, J.S.; Fernandez, M.L. Whole egg consumption improves lipoprotein profiles and insulin sensitivity to a greater extent than yolk-free egg substitute in individuals with metabolic syndrome. Metabolism 2013, 62, 400-410. [CrossRef] [PubMed]

29. Jones, J.L.; Fernandez, M.L.; McIntosh, M.S.; Najm, W.; Calle, M.C.; Kalynych, C.; Vukich, C.; Barona, J.; Ackermann, D.; Kim, J.E.; et al. A Mediterranean-style low-glycemic-load diet improves variables of metabolic syndrome in women, and addition of a phytochemical-rich medical food enhances benefits on lipoprotein metabolism. J. Clin. Lipidol. 2011, 5, 188-196. [CrossRef] [PubMed]

30. Al-Sarraj, T.; Saadi, H.; Calle, M.C.; Volek, J.S.; Fernandez, M.L. Carbohydrate restriction, as a first-line dietary intervention, effectively reduces biomarkers of metabolic syndrome in Emirati adults. J. Nutr. 2009, 139, 1667-1676. [CrossRef] [PubMed] 
31. Dugan, C.E.; Barona, J.; Fernandez, M.L. Increased dairy consumption differentially improves metabolic syndrome markers in male and female adults. Metab. Syndr. Relat. Disord. 2014, 12, 62-69. [CrossRef] [PubMed]

32. Friedewald, W.T.; Levy, R.I.; Fredrickson, D.S. Estimation of the concentration of low-density lipoprotein cholesterol in plasma, without use of the preparative ultracentrifuge. Clin. Chem. 1972, 18, 499-502. [PubMed]

33. Poehlman, E.T. Menopause, energy expenditure, and body composition. Acta Obstet. Gynecol. Scand. 2002, 81, 603-611. [CrossRef] [PubMed]

34. Izumi, Y.; Matsumoto, K.; Ozawa, Y.; Kasamaki, Y.; Shinndo, A.; Ohta, M.; Jumabay, M.; Nakayama, T.; Yokoyama, E.; Shimabukuro, H.; et al. Effect of age at menopause on blood pressure in postmenopausal women. Am. J. Hypertens. 2007, 20, 1045-1050. [CrossRef] [PubMed]

35. Kim, J.-M.; Kim, T.-H.; Lee, H.-H.; Lee, S.H.; Wang, T. Postmenopausal hypertension and sodium sensitivity. J. Menopausal. Med. 2014, 20, 1-6. [CrossRef] [PubMed]

36. Stachowiak, G.; Pertynnski, T.; Pertynska-Marczewska, M. Metabolic disorders in menopause. Prz. Menopauzalny 2015, 14, 59-64. [CrossRef] [PubMed]

37. Sites, C.K.; Toth, M.J.; Cushman, M.; L’Hommedieu, G.D.; Tchernof, A.; Tracy, R.P.; Poehlman, E.T. Menopause-related differences in inflammation markers and their relationship to body fat distribution and insulin-stimulated glucose disposal. Fertil. Steril. 2002, 77, 128-135. [CrossRef]

38. Ford, E.S.; Giles, W.H.; Dietz, W.H. Prevalence of the metabolic syndrome among US adults. J. Am. Med. Assoc. 2002, 287, 356-359. [CrossRef]

39. Lobo, R.A. Metabolic syndrome after menopause and the role of hormones. Maturitas 2008, 60, 10-18. [CrossRef] [PubMed]

40. Stevenson, J.C.; Crook, D.; Godsland, I.F. Influence of age and menopause on serum lipids and lipoproteins in healthy women. Atherosclerosis 1993, 98, 83-90. [CrossRef]

41. Expert Panel on Detection, Evaluation, and Treatment of High Blood Cholesterol in Adults. Executive Summary of the Third Report of the National Cholesterol Education Program (NCEP) Expert Panel on Detection, Evaluation, and Treatment of High Blood Cholesterol in Adults (Adult Treatment Panel III). JAMA 2001, 285, 2486-2497.

42. Ebron, K.; Andersen, C.J.; Aguilar, D.; Blesso, C.N.; Barona, J.; Dugan, C.E.; Jones, J.L.; Al-Sarraj, T.; Fernandez, M.L. A Larger body mass index is associated with increased atherogenic dyslipidemia, insulin resistance, and low-grade inflammation in individuals with metabolic syndrome. Metab. Syndr. Relat. Disord. 2015, 83, 291-295. [CrossRef] [PubMed]

43. Nicklas, B.; Penninx, B.; Ryan, A.; Berman, D.; Lynch, N.; Dennis, K. Visceral adipose tissue cutoffs associated with metabolic risk factors for coronary heart disease in women. Diabetes Care 2003, 26, 1413-1420. [CrossRef] [PubMed]

44. Arimura, S.T.; Moura, B.M.; Pimentel, G.D.; Silva, M.E.R.; Sousa, M.V. Circunferencia de la cintura es mejor asociado con lipoproteinas de alta densidad (LAD-C) que con el indice de masa corporal (IMC) en adultos con sindrome metabolico. Nutr. Hosp. 2011, 26, 1328-1332. [PubMed]

45. Özkaya, İ.; Bavunoglu, I.; Tunçkale, A. Body mass index and waist circumference affect lipid parameters negatively in Turkish women. Am. J. Public Health Res. 2014, 2, 226-231. [CrossRef]

46. Ebbert, J.O.; Jensen, M.D. Fat depots, free fatty acids, and dyslipidemia. Nutrients 2013, 5, 498-508. [CrossRef] [PubMed]

47. Thuren, T. Hepatic lipase and HDL metabolism. Curr. Opin. Lipidol. 2000, 11, 277-283. [CrossRef] [PubMed]

48. Chatterjee, C.; Sparks, D.L. Hepatic lipase, high density lipoproteins, and hypertriglyceridemia. Am. J. Pathol. 2011, 178, 1429-1433. [CrossRef] [PubMed]

49. Freemantle, N.; Holmes, J.; Hockey, A.; Kumar, S. How strong is the association between abdominal obesity and the incidence of type 2 diabetes? Int. J. Clin. Pract. 2008, 62, 1391-1396. [CrossRef] [PubMed]

50. Casanueva, F.F.; Moreno, B.; Rodriguez-Azeredo, R.; Massien, C.; Conthe, P.; Formiguera, X.; Barrios, V.; Balkau, B. Relationship of abdominal obesity with cardiovascular disease, diabetes and hyperlipidaemia in Spain. Clin. Endocrinol. Oxf. 2010, 73, 35-40. [CrossRef] [PubMed]

51. Lovejoy, J.; Champagne, C.; De Jonge, L.; Smith, S. Increased visceral fat and decreased energy expenditure during the menopausal transition. Int. J. Obes. 2008, 31, 949-958. [CrossRef] [PubMed]

52. Libby, P. Inflammation and Atherosclerosis. Circulation 2002, 105, 1135-1143. [CrossRef] [PubMed] 
53. Tall, A.R.; Yvan-charvet, L. Cholesterol, inflammation and innate immunity. Nat. Rev. Immunol. 2015, 15, 104-116. [CrossRef] [PubMed]

54. Murillo, A.G.; Fernandez, M.-L. Lycopene and lutein and the prevention of atherosclerosis: Is supplementation necessary? EC Nutr. 2015, 465-473.

55. Kaliora, A.C.; Dedoussis, G.V.Z.; Schmidt, H. Dietary antioxidants in preventing atherogenesis. Atherosclerosis 2006, 187, 1-17. [CrossRef] [PubMed]

56. Rodríguez, C.; González-Díez, M.; Badimon, L.; Martínez-González, J. Sphingosine-I-phosphate: A bioactive lipid that confers high-density lipoprotein with vasculoprotection mediated by nitric oxide and prostacyclin. Thromb. Haemost. 2009, 101, 665-673. [CrossRef] [PubMed]

57. Kuklina, E.V.; Yoon, P.W.; Keenan, N.L. Trends in high levels of low-density lipoprotein cholesterol in the United States. JAMA 2009, 310, 2104-2110. [CrossRef] [PubMed]

58. Santos-Gallego, C.G.; Giannarelli, C.; Badimón, J.J. Experimental models for the investigation of high-density lipoprotein-mediated cholesterol efflux. Curr. Atheroscler. Rep. 2011, 13, 266-276. [CrossRef] [PubMed]

59. Auro, K.; Joensuu, A.; Fischer, K.; Kettunen, J.; Salo, P.; Mattsson, H.; Niironen, M.; Kaprio, J.; Eriksson, J.G.; Lehtimäki, T.; et al. A metabolic view on menopause and ageing. Nat. Commun. 2014. [CrossRef] [PubMed]

60. Ansell, B.J.; Watson, K.E.; Fogelman, A.M.; Navab, M.; Fonarow, G.C. High-density lipoprotein function: Recent advances. J. Am. Coll. Cardiol. 2005, 46, 1792-1798. [CrossRef] [PubMed]

61. Angelica, M.D.; Fong, Y. HDL function, dysfunction, and reverse cholesterol transport. Atheroscler. Thromb. Vasc. Biol. 2008, 141, 520-529.

62. Mascarenhas-Melo, F.; Sereno, J.; Teixeira-Lemos, E.; Ribeiro, S.; Rocha-Pereira, P.; Cotterill, E.; Teixeira, F.; Reis, F. Markers of increased cardiovascular risk in postmenopausal women: Focus on oxidized-LDL and HDL subpopulations. Dis. Markers 2013, 35, 19-30. [CrossRef] [PubMed]

(C) 2016 by the authors; licensee MDPI, Basel, Switzerland. This article is an open access article distributed under the terms and conditions of the Creative Commons by Attribution (CC-BY) license (http:/ / creativecommons.org/licenses/by/4.0/). 